\title{
Increased vascular permeability in pancreas of diabetic rats: detection with high resolution protein A-gold cytochemistry
}

\author{
M.E. De Paepe ${ }^{1}$, M.Corriveau ${ }^{1}$, W.N.Tannous ${ }^{1}$, T. A.Seemayer ${ }^{1}$ and E. Colle $^{2}$ \\ Departments of ${ }^{1}$ Pathology and ${ }^{2}$ Endocrinology, McGill University-Montreal Children's Hospital Research Institute, Montréal, Canada
}

\begin{abstract}
Summary. The role of the pancreatic microcirculation in the pathogenesis of Type 1 (insulin-dependent) diabetes mellitus remains poorly understood. Herein, a method is described for the ultrastructural investigation of the integrity of the pancreatic microvasculature. The method consists of histochemical detection and isolation of the islets followed by albumin and protein A-gold immunocytochemistry, whereby the distribution of endogenous albumin is used as a marker of endothelial integrity. This technique, applied to the study of spontaneously diabetic rats, reveals a selective increase in permeability of islet capillaries and post-capillary venules at
\end{abstract}

the onset of diabetes, while acinar capillaries and arterioles remain intact. At 50 days of age, before the onset of diabetes, the microvasculature of diabetes-prone rats shows no alterations in permeability to albumin. When used in conjunction with morphometric analyses, this methodological approach may be useful for further studies in pathologic or experimental conditions involving the pancreatic microvasculature.

Key words: Diabetes mellitus, diabetic rat, albumin, protein A-gold, vascular permeability, electron microscopy.
BioBreeding (BB) rats spontaneously develop a diabetic syndrome resembling human Type 1 (insulin-dependent) diabetes mellitus [1]. There is increasing evidence that the disease, both in humans and in BB rats, results from autoimmune destruction of the insulin-producing Beta cells in the islets of Langerhans $[1,2]$. The importance of the pancreatic microvasculature in the pathogenesis of diabetes is suggested by functional [2-5] and morphological $[6,7]$ changes observed in the small vessels of the pancreas in early diabetes, even prior to the onset of insulitis. Furthermore, recent investigations have demonstrated pancreatic venular defects that are specific to the spontaneously diabetic $\mathrm{BB}$ rats [8] and that can be observed prior to insulitis [9].

Permeability studies of the pancreatic vasculature in animal models of diabetes have thus far been hampered by a variety of methodological limitations. The vascular damage noted in the islets of animals with streptozotocin-induced diabetes [3-5] is most likely secondary to the islet cell necrosis caused by the beta-cytotoxic agent, and may therefore not be related to diabetes per se. Exogenous markers of endothelial integrity such as Monastral blue B (MbB) (phthalocyanine) [8] and horseradish peroxidase induce changes in vascular permeability $[8,10,11]$ and thus may not reflect the vascular status under physiological conditions. Indeed, the pancreatic venular defect observed in
$\mathrm{BB} /$ Wor rats after injection with $\mathrm{MbB}$ is, at least in part, due to activation of intravascular monocytes by the pigment [8]. Finally, most studies have been performed at the light microscopic level $[3,4]$, making it difficult to localize and identify the exact vascular structures involved.

In the present study an alternative approach is used to investigate the integrity of the pancreatic microvasculature. Endogenous albumin, used as a marker of vascular permeability, is detected in spontaneously diabetic animals using an in situ morphocytochemical method, circumventing problems which occur with the use of exogenous tracers $[12,13]$. The determination of the endogenous albumin distribution as an approach for the study of vascular integrity has been employed previously to investigate the breakdown of the blood-brain barrier in ischaemia [14], the blood-nerve barrier in crush injury [15] and the blood-retina barrier in diabetes [16].

When combined with the high resolution protein Agold immunocytochemical technique, detection of albumin can be performed at the electron microscopic level, allowing for precise localization of the marker. Moreover, the particulate nature of the gold label permits quantification and morphometric analyses [17]. This high resolution method has been previously applied to the study of capillary permeability of retina [18], pancreas and colon [19] and of glomerular permeability in diabetes $[20,21]$. 
The ultrastructural study of pancreatic islets is a laborious task, unless the islets are first isolated from the surrounding exocrine pancreas. We therefore searched for an islet isolation method compatible with subsequent postembedding albumin and protein A-gold immunocytochemistry. The aim of the present study was: (1) to test the usefulness of a dithizone (diphenylthiocarbazone)-based islet isolation method [22] to be performed in conjunction with subsequent albumin and protein A-gold immunocytochemistry and, (2) to apply this method to the study of the integrity of the pancreatic microvasculature of diabetes-prone rats prior to and at the time of onset of diabetes.

\section{Materials and methods}

\section{Animals}

Vascular permeability to albumin was studied in diabetes-prone (DP) rats, before and after the onset of clinical diabetes, and in agematched diabetes-resistant (DR) rats. The DP and DR animals were bred in our own colony. They are the result of 21 generations of brother-sister matings from a cross between a Buffalo female and a male diabetic BB rat from the Ottawa colony. Both DP and DR animals are RT1. ${ }^{\mathrm{w} u}$. The DR rats have had normal numbers of $\mathrm{T}$ lymphocytes for eight generations and no diabetes has occurred during that time. The DP animals are lymphopoenic and the animals used in this study are from litters in which at least one parent was diabetic. The incidence of diabetes in such litters is $70-80 \%$. All animals were maintained on Purina rat chow and tap water ad libitum. Six DP rats were killed at age 50 days, prior to the onset of clinical diabetes. Six other DP rats were killed within 2 days after the onset of diabetes (days 78 to 140). The onset of diabetes was determined by an increase in daily urine volume $(>20 \mathrm{ml})$ and plasma glucose levels $(>16 \mathrm{mmol} / 1)$. Age-matched DR rats $(n=3)$ were killed at age 50-150 days. Experiments were conducted in accordance with the guidelines of the McGill University Animal Care Committee and the Canadian Council of Animal Care.

\section{Preparation of islets}

The pancreas was carefully resected and briefly rinsed in ice-cold $0.1 \mathrm{~mol} / \mathrm{l}$ cacodylate buffer, $\mathrm{pH}$ 7.45. Part of the organ was fixed in Bouin's solution, embedded in paraffin and stained with haematoxylin-eosin. The remainder of the tissue was prefixed by immersion in $0.5 \%$ para-formaldehyde and $0.1 \%$ glutaraldehyde in $0.1 \mathrm{~mol} / 1$ cacodylate, $\mathrm{pH} 7.45$, for $10 \mathrm{~min}$, and then exposed to $0.12 \mathrm{mmol} / 1 \mathrm{di}-$ thizone in the same fixation solution for $5 \mathrm{~min}$ [22]. The islets were microdissected and further fixed in $4 \%$ para-formaldehyde and $0.1 \%$ glutaraldehyde in $0.1 \mathrm{~mol} / \mathrm{l}$ cacodylate at $4^{\circ} \mathrm{C}$ for $2 \mathrm{~h}$, followed by washes in cacodylate buffer.

Low temperature embedding with Lowicryl K4M resin (Chemische Werke Lowi GmbH, Wald Kraiburg, FRG) was performed as follows: tissue pieces stored in cacodylate buffer at $4^{\circ} \mathrm{C}$ were transferred into $30 \%$ ethanol at $0^{\circ} \mathrm{C}$ for $30 \mathrm{~min}$. Further dehydration was carried out at progressively lower temperatures: $50 \%$ ethanol for $1 \mathrm{~h}$ at $-20^{\circ} \mathrm{C}, 70 \%$ ethanol for $1 \mathrm{~h}$ at $-35^{\circ} \mathrm{C}$, and $100 \%$ ethanol two times for $1 \mathrm{~h}$ each at $-35^{\circ} \mathrm{C}$. Lowicryl K4M-ethanol mixtures were used at consecutive volume ratios of 1:1 and 2:1 (resin:ethanol) for $1 \mathrm{~h}$ each at $-35^{\circ} \mathrm{C}$. The tissue was then transferred to gelatin capsules and the resin was polymerized by ultra violet irradiation at $-35^{\circ} \mathrm{C}$ for $24 \mathrm{~h}$ and at room temperature for a further $48 \mathrm{~h}$.

In two animals (one normoglycaemic DP, one DR) all visualized dots were dissected and embedded. One-micron-thick sections of these tissue blocks were stained with toluidine blue and examined by light microscopy to assess the specificity of the dithizone detection method. In the remaining animals five randomly selected dithizonestained foci were embedded per animal. Thin sections of the Lowicryl-K4M embedded pancreata were cut with diamond knives and placed on parlodion-coated nickel grids. For morphologic studies the sections were then stained with uranyl-acetate and lead-citrate and examined with a Philips EM 301 transmission electron microscope at an accelerating voltage of $60 \mathrm{kV}$.

\section{Immunohistochemical labelling}

For the ultrastructural localization of endogenous albumin, the protein A-gold post-embedding immunocytochemical technique was applied [17]. Colloidal gold particles $15 \mathrm{~nm}$ in size were prepared according to techniques described elsewhere [23] using sodium citrate as the reducing agent. For ultrastructural localization of albumin in the pancreatic vessels, thin sections were incubated with a rabbit antibody against rat albumin (Organon Teknika Corp West Chester, $\mathrm{Pa}$., USA) at a $1 / 100$ dilution in phosphate-buffered saline (PBS) $\mathrm{pH} 7.2$ at room temperature for $1 \mathrm{~h}$. The grids were washed in PBS and incubated with the protein A-gold complex at room temperature for $1 \mathrm{~h}$. The grids were thoroughly washed in PBS, rinsed in distilled water and lightly stained with uranyl acetate and lead citrate.

The specificity of immunolabelling was assessed by the following controls: (1) preadsorption of the antibody by its specific antigen (rat serum albumin; Sigma Chemical Co., St. Louis, Mo., USA) for $12 \mathrm{~h}$ at $4^{\circ} \mathrm{C}$ (control for specificity of the antigen-antibody reaction), (2) omission of the primary antibody and incubation with the protein A-gold complex alone (control for non-specific adsorption of protein A-gold to the tissue section), and (3) substitution of the specific antibody by normal rabbit serum (control for non-specific adsorption of immunoglobulins to the tissue section).

\section{Morphometrical analyses}

Quantitative evaluation of the labelling of insular and acinar capillaries was performed based upon the approach described by Bendayan [17]. Insular capillaries were defined as capillaries located within the islet or at its periphery. Acinar capillaries were taken at random from the exocrine tissue surrounding the islets. Fields containing capillaries were first selected at $\times 3000$, a magnification at which gold particles are not discernible. Micrographs were then taken at $\times 15,000$ and enlarged to a final magnification of $\times 37,500$. Twelve pictures, representing at least three insular and acinar capillaries, were recorded per animal. The intra- and extra-capillary surface areas were determined by direct planimetry. For this purpose intra-capillary area was defined as the surface area occupied by the capillary lumen, excluding blood corpuscles, whereas the extra-capillary area was defined as the area occupied by capillary basement membrane and attached collagen. The number of gold particles over these areas was then counted and the labelling density, expressed as the number of gold particles per $\mu^{2}{ }^{2}$ of selected area, calculated. Finally, the ratio of extra-capillary labelling density (ECD) over intracapillary labelling density (ICD) was determined per capillary.

In order to quantitate the background labelling, the following labelling densities were recorded: (1) nuclei in the experimental protocol and (2) intra- and extra-capillary spaces in control experiments using normal rabbit serum instead of specific antibody. The labelling density was obtained as indicated above and expressed as the number of gold particles per $\mu \mathrm{m}^{2}$.

\section{Statistical analysis}

The mean ECD/ICD ratio obtained for normoglycaemic animals was compared to that found for early diabetic animals using a twosample $t$ test whereby a $p$ value $<0.05$ was considered statistically significant. 

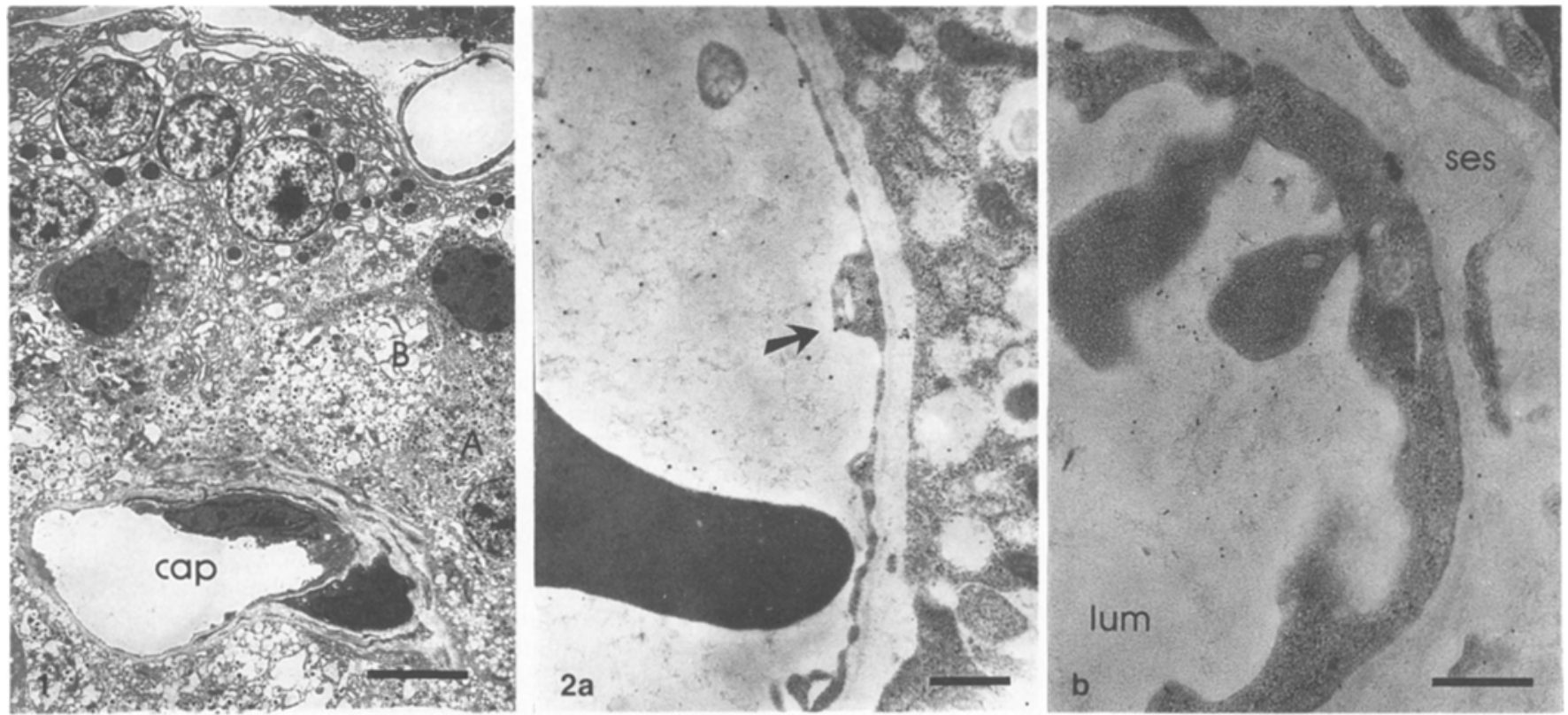

Fig. 1. Normoglycaemic diabetes-prone rat. Islet (lower two-thirds), exocrine pancreas (upper one-third) and islet capillary (cap) showing satisfactory preservation. (A) presumably Alpha cell (glucagon), (B) Beta cell (insulin). Magnification $\times 3,500$; bar, $5 \mu \mathrm{m}$

Fig.2. (a) Islet capillary, diabetes-resistant rat. Gold labelling over proteinaceous material in lumen (left, with erythrocyte). Little or no labelling over thin, flat endothelium (arrow), basal lamina and ad-

\section{Results}

Histology

Four of the six newly-diabetic DP rats showed active insulitis associated with varying degrees of acinar and periductular inflammation. The remaining two diabetic animals showed smallend-stage islets devoid of inflammation. There were no signs of insulitis in the pancreata of nondiabetic DP rats killed at day 50 and of control DR rats, although two of the six normoglycaemic DP rats displayed mild degrees of periductular and acinar inflammation.

\section{Dithizone detection and islet isolation}

After 15 to $30 \mathrm{~min}$ of immersion in the dithizone-fixative solution, the pancreata displayed bright red dots, evenly distributed throughout the organ, and readily visible under the dissecting microscope. The number of islets per animal so detected ranged between 27 and 52 (mean 39) in the DR animals, between 17 and 42 (mean 33) in the normoglycaemic DP rats and between 12 and 33 (mean 18) in the newly-diabetic DP rats. The detection method proved to be highly specific: $91 \%$ of the embedded tissue blocks (68 of 75 ) contained islets.

\section{Ultrastructural morphology}

The ultrastructural detail of islets, surrounding exocrine pancreas, and vessels was well preserved (Fig. 1). The islet cells showed satisfactory preservation of their cytoplasmic jacent islet cell (right, with cytoplasmic granules). Magnification $\times 28,000$; bar, $0.5 \mu \mathrm{m}$. (b) Islet capillary, newly-diabetic diabetes-prone rat. Thickened endothelium showing prominent bulbous and villous cytoplasmic projections. Moderate gold labelling is present over the endothelium and subendothelial space (ses). lum, capillary lumen. Magnification $\times 35,500$; bar, $0.5 \mu \mathrm{m}$

granules, allowing presumptive identification of the various endocrine cells. The diameter of the islets ranged from $220 \mu \mathrm{m}$ to $650 \mu \mathrm{m}$ (mean diameters $410 \mu \mathrm{m}$ and $380 \mu \mathrm{m}$ for DR and normoglycaemic DP rats, respectively). The rim of exocrine pancreas surrounding the islets was between $50 \mu \mathrm{m}$ and $550 \mu \mathrm{m}$ wide. In newly-diabetic animals the pancreas exhibited mononuclear cell infiltration of islets and acinar tissue associated with degranulation, increased membrane systems and occasional necrosis of the Beta cells. The islet morphology of the young normoglycaemic DP rats was indistinguishable from that of DR rats.

Based on morphologic criteria, the various types of microvascular structures could be easily identified. The islets contained predominantly capillaries, although at their periphery occasionally arterioles could be observed. The exocrine tissue showed a greater variety of vessels, including capillaries, arterioles and post-capillary venules. In DR and normoglycaemic DP animals, the endothelium of capillaries and post-capillary venules was flat and devoid of cytoplasmic projections (Fig. 2a). In newly-diabetic animals the endothelial cells of the insular and acinar capillaries and of the post-capillary venules showed irregular cytoplasmic projections and nuclear protrusion towards the lumen (Fig. 2b).

\section{Albumin immunocytochemistry}

In all animals there was intense immunocytochemical la belling of flocculent material in the vascular lumina, representing serum proteins retained throughout the islet iso- 

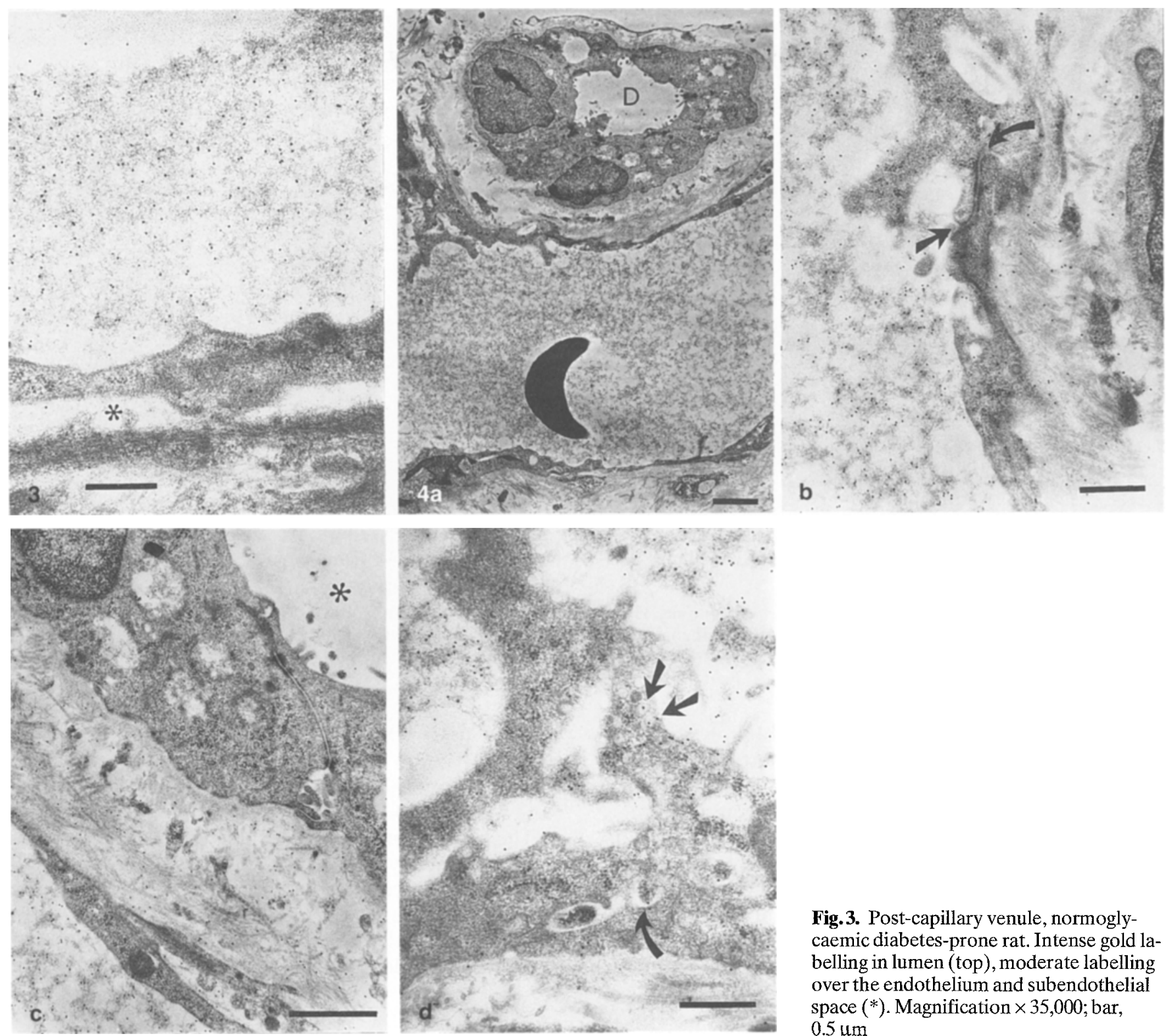

Fig. 3. Post-capillary venule, normoglycaemic diabetes-prone rat. Intense gold labelling in lumen (top), moderate labelling over the endothelium and subendothelial space $(*)$. Magnification $\times 35,000$; bar, $0.5 \mu \mathrm{m}$

Fig.4a-d. Post-capillary venule, newly-diabetic diabetes-prone rat. (a) Low power view showing ductule (D) in close association with venule (bottom, with erythrocyte). Magnification $\times 5,500$; bar, $2 \mu \mathrm{m}$. (b) Numerous gold particles are present over the venular lumen (left), endothelium and subendothelial space (right). Labelling is seen in association with several plasmalemmal vesicles (above and below intercellular junction, marked by arrows). Note the villous projection of the endothelial cell. Magnification $\times 30,500$; bar,
$0.5 \mu \mathrm{m}$. (c) Heavy gold labelling over venular lumen (bottom left), endothelium and subendothelial space. The adjacent ductular epithelium and lumen (*) are virtually free of labelling. Magnification $\times 21,500$; bar, $1 \mu \mathrm{m}$. (d) Markedly irregular outlines of the endothelial cells, showing close association of gold labelling with plasmalemmal vesicles (arrows). (Lumen above, subendothelial space below.) Magnification $\times 36,500$; bar, $0.5 \mu \mathrm{m}$. Note: Figures $4 \mathrm{~b}-\mathrm{c}$ represent high power views of field shown in Figure $4 \mathrm{a}$ lation and fixation procedures. In non-diabetic animals, whether DR or young DP, the insular capillaries demonstrated only sparse immunostaining outside of the lumen (Fig. 2a). In animals examined at the onset of diabetes, the islet capillaries showed enhanced gold labelling over the endothelial cells and subendothelial spaces (Fig.2b). Similarly, the post-capillary venules of diabetic animals showed increased labelling intensity over the endothelium and subendothelial and perivascular spaces, whereas in non-diabetic animals labelling was virtually limited to proteinaceous material in the lumen (Figs. 3 and $4 \mathrm{a}-\mathrm{c}$ ).
The extravascular labelling appeared to be increased to the same degree in diabetic animals with and without evidence of insulitis. At the cellular level, endothelial gold labelling was often seen in association with plasmalemmal vesicles (Fig. 4 d) or - particularly in the post-capillary venules - with intercellular junctions (Fig.5).

In acinar capillaries and arterioles, the intensity of the gold labelling was similar for normoglycaemic and diabetic animals. The arterioles displayed a characteristic pattern of staining showing a high intensity of gold particles in the subendothelial spaces and in the pericellular 


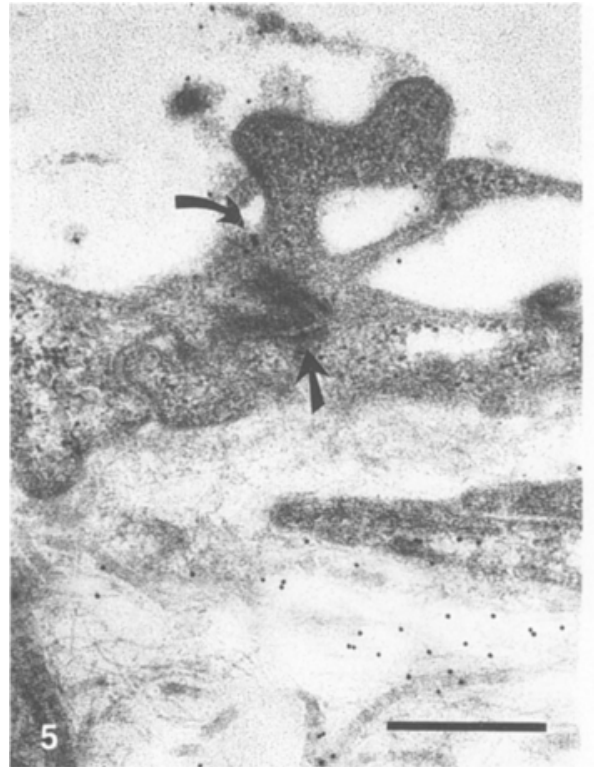

Fig.5. Post-capillary venule, newly-diabetic diabetes-prone rat. Gold labelling over intercellular junction between endothelial cells (arrows). Magnification $\times 50,500 ;$ bar, $0.5 \mu \mathrm{m}$

Fig. 6. Acinar arteriole, normoglycaemic diabetes-prone rat. Gold particles are abundant in vascular lumen (lum), subendothelial space
(*), and pericellular spaces between smooth muscle cells (arrow). Magnification $\times 14,500$; bar, $1 \mu \mathrm{m}$

Fig.7. Abolition of labelling after preadsorption of antibody with antigen, representative of all controls of specificity. lum, capillary lumen. Magnification $\times 30,000 ;$ bar, $0.5 \mu \mathrm{m}$ spaces between the smooth muscle cells, sharply contrasting with the virtually non-staining smooth muscle cells (Fig.6). Nuclei, mitochondria and cytoplasmic granules (zymogen or insulin) were largely free of staining.

Controls. Omission of the primary antibody, preadsorption of the anti-albumin antibody with its antigen and substitution of the specific antibody with normal rabbit serum resulted in abolition or significant diminution of staining (Fig.7).

\section{Morphometrical studies}

In the capillaries the qualitative observations made concerning the intensity of albumin labelling were confirmed by quantitative analysis (Table 1 ). The mean ICD values of the capillaries, representing the gold labelling densities of the capillary lumina, showed little variation, indicating consistently good preservation of the luminal content during the experimental protocol. The mean $\mathrm{ECD} / \mathrm{ICD}$ ratio of islet capillaries was significantly higher under diabetic conditions $(0.30 \pm 0.15, n=20)$ than under normoglycaemic conditions $(0.14 \pm 0.08, n=7$, and $0.10 \pm 0.09$, $n=21, p<0.01)$. The mean ECD/ICD ratio of islet capillaries was comparable between diabetic animals with and without evidence of insulitis $(0.32 \pm 0.18, n=14$ vs $0.27 \pm 0.17, n=6$ ). There was no significant difference between the mean ECD/ICD ratio of islet capillaries of DR animals $(0.14 \pm 0.08, n=7)$ and that of $\mathrm{DP}$ animals prior to the onset of diabetes $(0.10 \pm 0.09, n=21)$. The mean $\mathrm{ECD} / \mathrm{ICD}$ ratio of the two normoglycaemic DP rats with acinar inflammation $(0.11 \pm 0.09)$ was similar to that of the normoglycaemic DP animals without any sign of inflam- mation $(0.09 \pm 0.08)$. In non-diabetic animals the ECD/ICD ratio was higher for acinar capillaries $(0.28 \pm 0.05$ and $0.22 \pm 0.11)$ than for insular capillaries $(0.14 \pm 0.08$ and $0.10 \pm 0.09)$.

The background labelling evaluated on nuclei resulted in average density of labelling of $0.17 \pm 0.09$ particles $/ \mu \mathrm{m}^{2}$, both in normoglycaemic and diabetic animals. In control experiments the background labelling density was $0.12 \pm 0.09$ particles $/ \mu \mathrm{m}^{2}$ over the capillary lumina and $0.09 \pm 0.06$ particles $/ \mu \mathrm{m}^{2}$ in extra-capillary sites.

\section{Discussion}

The ultrastructural localization of endogenous albumin, used as a marker of vascular integrity, was revealed in the rat pancreas by applying the protein A-gold immunocytochemical approach. To allow specific investigation of the microvasculature in and around the islets, the islets were first marked with dithizone (diphenylthiocarbazone) and isolated by microdissection [22]. In our hands this islet detection method resulted in the isolation of 12 to 52 islets per animal, a yield slightly lower than that obtained by other visualization methods [3]. The islets thus isolated are intermediate- to large-sized, as indicated by their diameter $(220 \mu \mathrm{m}$ to $650 \mu \mathrm{m})$ and their close association with major branches of blood vessels and large ducts [24]. The dithizone technique is less sensitive in diabetic rats at an early stage of disease than in non-diabetic animals. This loss of sensitivity probably results from the Beta-cell degranulation described in early diabetes [25], since the dithizone method is based on the histochemical detection of zinc contained in insulin. 
Table 1. Gold labelling densities of islet and acinar capillaries

\begin{tabular}{llll}
\hline & $\begin{array}{l}\text { ECD } \\
(\text { particles }\end{array}$ & ICD & ECD/ICD \\
per $\left.\mu \mathrm{m}^{2}\right)$ & perticles $\left.\mu \mathrm{m}^{2}\right)$ & \\
\hline
\end{tabular}

Islet capillaries

DR rats (3)

$1.90 \pm 0.83 \quad 13.90 \pm 4.87 \quad 0.14 \pm 0.08$

$\begin{array}{lllll}\text { Normoglycaemic DP rats (6) } & 1.32 \pm 0.64 & 13.66 \pm 5.54 & 0.10 \pm 0.09\end{array}$

Diabetic DP rats (6)

$\begin{array}{lll}4.63 \pm 2.38 & 15.20 \pm 6.97 & 0.30 \pm 0.15\end{array}$

Acinar capillaries

DR rats (3)

$3.87 \pm 1.89 \quad 13.87 \pm 2.97 \quad 0.28 \pm 0.05$

$\begin{array}{llll}\text { Normoglycaemic DP rats (6) } & 2.84 \pm 2.16 & 12.74 \pm 3.87 & 0.22 \pm 0.11\end{array}$

$\begin{array}{llll}\text { Diabetic DP rats (6) } \quad 3.50 \pm 2.84 & 14.42 \pm 6.31 & 0.24 \pm 0.13\end{array}$

Values are expressed as mean $\pm S D$. Numbers in parentheses represent number of animals examined. DR, Diabetes resistant; DP, diabetes prone; ECD, extra-capillary labelling density (number of gold particles per $\mu^{2}$ of area occupied by capillary basement membrane and attached collagen); ICD, intra-capillary labelling density (number of gold particles per $\mu \mathrm{m}^{2}$ of capillary lumen)

The present experimental protocol ensures the in situ retention of endogenous albumin, as indicated by the consistent, intense gold labelling over intravascular proteinaceous material. Consequently, colloidal protein A-gold immunocytochemistry can be used in a post-embedding approach, avoiding problems of antigen accessibility and of penetration of the tracer [17].

In non-diabetic animals the islet capillaries and post-capillary venules exhibited a low permeability to albumin, as evidenced by the low density of gold particles, representing albumin antigenic sites, around these structures. This is in agreement with previous protein A-gold immunocytochemistry studies in Wistar-Furth rats which have demonstrated that, under non-diabetic conditions, the capillary endothelium of the endocrine pancreas is restrictive to albumin [19]. In non-diabetic animals the endothelium of the acinar capillaries appeared to be more permeable to albumin than that of isletcapillaries, a finding previously suggested by Hart and Pino [19]. Relatively intense gold labelling was noted in the wall of arterioles. The pattern of staining observed in these structures, particularly the intense labelling of the subendothelialspaces and of the pericellular spaces between the smooth muscle cells, has also been described in the wall of large arteries [26].

Newly-diabetic DP rats showed a higher concentration of albumin antigens outside the islet capillaries and postcapillary venules than DR animals. In the islet capillaries this qualitative observation was confirmed with quantitative analyses based upon the distribution of labelling over intra- and extra-capillary sites. This increase in permeability for albumin seems to be specific for islet capillaries and post-capillary venules, as the integrity of the acinar capillaries and arterioles remained unchanged after the onset of diabetes. There was no obvious increase in albumin permeability in the islet capillaries of young DP rats prior to the onset of diabetes, which suggests that the changes are due to the disease process itself rather than to genetic differences.

Increased permeability of islet capillaries [4] and postcapillary venules $[3,9]$ in diabetic rats has been described before. However, previous studies were based upon the light microscopic detection of changes in vascular integrity, using Evans blue [4] and $\mathrm{MbB}$ vascular labelling $[3,9]$. Furthermore, in two of these studies the diabetes was streptozotocin induced $[3,4]$. With the present method these permeability changes can be observed at the ultrastructural level in the spontaneously diabetic rat. The use of an endogenous, naturally occurring marker of vascular integrity avoids the potential bias associated with the use of exogenous substances.

At the cellular level gold particles revealing albumin antigenic sites were frequently observed in association with endothelial plasmalemmal vesicles, both in capillaries and post-capillary venules. Plasmalemmal vesicles have previously been implicated in the transendothelial transport of circulating proteins [12, 27-29] although this subject remains highly controversial and is under ongoing investigation $[29,30]$. In post-capillary venules gold particles were occasionally observed over intercellular junctions, which might suggest this transport pathway as a secondary mechanism for the movement of albumin across the endothelium. From the present data however, the direction of this movement, either from the venular lumen towards the interstitium or vice versa, cannot be determined.

In conclusion, dithizone-detection of the islets in combination with albumin and protein A-gold immunocytochemistry allows high resolution studies of the morphology and permeability of the pancreatic microvasculature, more specifically in and around the islets of Langerhans. Preliminary studies in spontaneously diabetic rats indicate that there is a selective increase in permeability of the islet capillaries and post-capillary venules at the onset of diabetes. When used in conjunction with morphometric analyses, this method may be useful for further studies in pathologic or experimental conditions involving the pancreatic microvasculature.

Acknowledgements. The authors are grateful to Dr. M.Bendayan (Department of Anatomy, Université de Montréal) for constructive discussions and critical review of the manuscript. The excellent technical assistance of Ms. R. Grabs is acknowledged. This work was supported by grants from the Medical Research Council of Canada. Dr. De Paepe is a recipient of fellowships from the Diabetic Children's Foundation, the N.A.T.O., and the McGill University-Montreal Children's Hospital Research Institute.

\section{References}

1. Marliss EB, Nakhooda AF, Poussier P, Sima AAF (1982) The diabetic syndrome of the "BB" Wistar rat: possible relevance to type 1 (insulin-dependent) diabetes in man. Diabetologia 22: 225-232

2. Rossini AA, Mordes JP, Like AA (1985) Immunology of insulindependent diabetes mellitus. Ann Rev Immunol 3: 291-322

3. Sandler S, Jansson L (1985) Vascular permeability of pancreatic islets after administration of streptozotocin. Virchows Arch [A] 407:359-367

4. Beppu H, Maruta K, Kürner T, Kolb H (1987) Diabetogenic action of streptozotocin: essential role of membrane permeability. Acta Endocrinol (Copenh) 114: 90-95

5. Papaccio G, Chieffi-Baccari G, Mezzogiono V, Esposito V (1990) Capillary area in early low-dose streptozotocin-treated mice. Histochemistry 95: 19-21 
6. Hanenberg H, Kolb-Bachofen V, Kantwerk-Funke G, Kolb H (1989) Macrophage infiltration precedes and is a prerequisite for lymphocytic insulitis in pancreatic islets of pre-diabetic BB rats. Diabetologia 32: 126-134

7. Yamamoto K, Miyagawa J-I, Hanafusa T, Kono N, Tarui S (1991) Early ultrastructural changes of endothelial cells in insulitis of NOD mice. Diabetes 40: 291A (Abstract)

8. Majno G, Joris I, Handler ES, Desemone J, Mordes JP, Rossini AA (1987) A pancreatic venular defect in the BB/Wor rat. Am J Pathol 128: 210-215

9. Nakai M, Uno K, Nakano K et al. (1991) The role of macrophage in pancreatic venular leakage in the BB/W rat. Diabetes $40: 218 \mathrm{~A}$ (Abstract)

10. Cotran RS, Karnovsky MJ (1967) Vascular leakage induced by horseradish peroxidase in the rat. Proc Soc Exp Biol Med 126: $557-561$

11. Simionescu N (1979) Enzymatic tracers in the study of vascular permeability. J Histochem Cytochem 27:1120-1130

12. Bendayan M (1980) Use of the protein A-gold technique for the morphological study of vascular permeability. J Histochem Cytochem 28: 1251-1254

13. Pino RM (1989) Cytochemical studies of the vascular endothelium. Prog Histochem Cytochem 19: 1-38

14. Liu HM (1988) Neovasculature and blood-brain barrier in ischemic brain infarct. Acta Neuropathol 75: 422-426

15. Mata M, Staple J, Fink DJ (1988) Distribution of albumin-like immunoreactivity in rat sciatic nerve after nerve crush injury. $J$ Neuropath Exp Neurol 47: 271-281

16. Vinores SA, Gadegbeku C, Campochiaro PA, Green WR (1989) Immunohistochemical localization of blood-retinal barrier breakdown in human diabetics. Am J Pathol 134: 231-235

17. Bendayan M (1984) Protein A-gold immunocytochemistry: technical approach, applications and limitations. J Electr Microsc Tech 1:243-270

18. Pino RM, Thouron CL (1983) Vascular permeability in the rat eye to endogenous albumin and immunoglobulin $\mathrm{G}(\mathrm{IgG})$ examined by immunohistochemical methods. J Histochem Cytochem 31: 411-416

19. Hart TK, Pino RM (1986) Capillary permeability in the pancreas and colon: restriction of exogenous and endogenous molecules by fenestrated endothelia. Am J Anat 175: 49-58

20. Bendayan M, Gingras D, Charest P (1986) Distribution of endogenous albumin in the glomerular wall of streptozotocin-induced diabetic rats as revealed by high-resolution immunocytochemistry. Diabetologia 29: 868-875
21. Russo PA, Bendayan M (1990) Distribution of endogenous albumin in the glomerular wall of proteinuric patients. Am J Pathol 137: 1481-1490

22. In't Veld PA, Pipeleers DG (1988) In situ analysis of pancreatic islets in rats developing diabetes. Appearance of nonendocrine cells with surface MHC class II antigens and cytoplasmic insulin immunoreactivity. J Clin Invest 82: 1123-1128

23. Frens $G$ (1973) Controlled nucleation for regulation of the particle size in monodisperse gold suspensions. Nature Phys Sci 241: 20-22

24. Bonner-Weir S, Orci L (1982) New perspectives on the microvasculature of the islets of Langerhans in the rat. Diabetes 31: 883889

25. Seemayer TA, Tannenbaum GS, Goldman H, Colle E (1982) Dynamic time course studies of the spontaneously diabetic BB Wistar rat. III. Light microscopic and ultrastructural observations of pancreatic islets of Langerhans. Am J Pathol 106: 237-249

26. Londono I, Bendayan M (1989) Distribution of endogenous albumin across the rat aortic wall as revealed by quantitative immunocytochemistry. Am J Anat 186: 407-416

27. Ghitescu L, Fixman A, Simionescu M, Simionescu N (1986) Specific binding sites for albumin restricted to plasmalemmal vesicles of continuous capillary endothelium: receptor-mediated transcytosis. J Cell Biol 102: 1304-1311

28. Muresan V (1986) Pathways of transcytosis in the fenestrated endothelium of pancreatic capillaries. J Submicrosc Cytol 18: 691700

29. Milici AJ, Watrous NE, Stukenbrok H, Palade GE (1987) Transcytosis of albumin in capillary endothelium. J Cell Biol 105: 2603-2612

30. Palade GE (1988) The microvascular endothelium revisited. In: Simionescu N, Simionescu M (eds) Endothelial cell biology. Plenum Press, New York, pp 3-22

Received: 20 May 1992

and in revised form: 3 August 1992

Dr. M. De Paepe

AZ-Vrije Universiteit Brussel

Experimentele Pathologie

Laarbeeklaan 103

B-1090 Brussels

Belgium 